\title{
Analysis of Cellulolytic Bacterial Flora in the Rumen of Inner Mongolian Sheep
}

Jianguo Liu, ${ }^{\text {a,b }}$ Zhanying Liu,, b,,$*$ Yucheng Liu, ${ }^{\mathrm{d}}$ Min Hao, ${ }^{\mathrm{b}, \mathrm{c}}$ and Xianzhi Hou ${ }^{\mathrm{d}}$

The cellulolytic bacterial flora present in the rumen of Inner Mongolian sheep are thought to have a high degree of cellulose-degrading activity because of their foraging feeding regimen. However, there are no report on the genetic and species composition of the cellulolytic bacterial flora. In this study, cellulolytic bacteria were isolated from the rumen of Inner Mongolian sheep using a combined method of transparent zone and filter paper degradation. Twenty-two strains were identified via morphological, physiological, and biochemical tests. Ten strains were further identified via DNA $(G+C)$ mol\%, together with 165 rDNA gene sequencing analysis. Four types of extracellular and total cellulase activities of representative strains were determined. The results demonstrated that the isolates included Butyrivibrio fibrisolvens, Rumincoccus albus, R. flavefaciens, Fibrobacter succinogenes, and Clostridium polysaccharolyticum. A big proportion of cellulolytic Butyrivibrio fibrisolvens was found in the rumen of Inner Mongolian sheep. This was the first study to analyze the cellulolytic bacterial flora in the rumen of foraging Inner Mongolian sheep. These results indicated that the rumen of Inner Mongolian sheep represents an attractive source for cellulolytic microorganisms and enzymes, and the research results have a certain guiding importance for the efficient degradation of cellulosic materials.

Keywords: Cellulolytic bacterial flora; Rumen; Inner Mongolian sheep

Contact information: a: Department of Environmental Science and Engineering, Inner Mongolia University of Technology, Hohehot 010051, China; b: Center for Energy Conservation and Emission Reduction in Fermentation Industry, Inner Mongolia, Hohehot 010051, China; c: School of Chemical Engineering, Inner Mongolia University of Technology, Hohehot 010051, China; d: School of Animal Science, Inner Mongolia Agricultural University, Hohhot 010018, China;

* Corresponding authors: hgxylzy2008@imut.edu.cn

\section{INTRODUCTION}

The production of biofuels from renewable lignocellulosic biomass has received tremendous attention both in the energy industry and in academic communities worldwide based on the demand for sustainable economies and clean energy (Sanderson 2006; Lynd et al. 2008). Cellulosic resources, the most abundant biomass on earth, have the greatest potential to resolve the energy crisis (Sanchez and Cardona 2008; Weimer et al. 2015) because they can be converted to biofuels by hydrolysis and subsequent fermentation (Lane 1991; Hamelinck et al. 2005). Hydrolysis is a rate-limiting step because of the recalcitrance of lignocellulose. Among the various available approaches, enzymatic hydrolysis is more environmentally sound compared with acid-reliant or base-reliant hydrolytic and thermochemical processes (Hamelinck et al. 2005). However, the paucity of enzymes or microbes that efficiently deconstruct the plant polysaccharides represents a bottleneck for the hydrolysis of lignocellulose and therefore to the industrial-scale conversion of cellulosic biomass into biofuels (Hess et al. 2011). As a result, the exploration of 
cellulolytic microorganisms and cellulases is important. The rumen ecosystem is the most efficient system for cellulose transformation to valuable products (Nouaille et al. 2009), with many rumen microbes specializing in the degradation of cellulosic plant materials (Hess et al. 2011). The rumen cellulolytic microorganisms, which possess very active and complex hydrolytic systems, are thus potential biocatalysts for biofuel production (Nouaille et al. 2009). However, most members of this complex community are not cultivable (Hess et al. 2011). Few studies have focused on strain isolation from the rumen due to the sensitivity to oxygen and special medium requirements (Kenters et al. 2011). Furthermore, molecular biology methods have demonstrated that $<1 \%$ of the known rumen microbe has been isolated (Pitta et al. 2014). Surveys of the 16S rDNA genes of bacteria in the rumen of various ruminants have indicated a vast diversity of bacterial genera and species that have not yet been characterized (Kenters et al. 2011). The development of molecular biological methods has explored the rumen microbial flora in different types of ruminants. These studies have demonstrated the structure of microbial flora to be dynamic and regulated by numerous factors, such as host, diet, physiological status, geographical location, season, and feeding regimen (Thomas et al. 2011; Pitta et al. 2014, 2016). A metagenomic study of Mehsani buffalo rumen identified a significantly higher abundance of microbiome in green roughage fed animals compared with dry roughage fed animals (Patel et al. 2014). Ghasemi et al. (2012) demonstrated that the inclusion of pistachio hulls as a replacement for alfalfa hay in the diet of sheep caused a shift in the rumen cellulolytic bacterial population (Ghasemi et al. 2012). There are several reports regarding the isolation of rumen bacteria from the rumen of Creole goats (Grilli et al. 2013), cows (Kenters et al. 2011; Hungate 2013), sheep (Hungate 2013), and bovines (Nyonyo et al. 2014), each with diverse microbial flora found in the different ruminants. The above studies suggest that the type of ruminant, diet, and geographical location affects the kind and abundance of microbial flora.

In the Inner Mongolian region, the weather is cold, dry, and the ruminant feeding regimen comprises a large number of forage species. Different ruminants in this region are thought to have microbial flora consisting of various types and proportions of cellulolytic microorganisms. Sheep is a typical ruminant of Inner Mongolia (Lim et al. 2015). However, to the best of the authors' knowledge, there are no reports regarding the isolation of cellulolytic bacteria in the rumen of Inner Mongolian sheep.

In this study, the authors isolated cellulolytic bacteria using a combined method and systematically identified the isolates using traditional identification and molecular biology methods. Representative strains were selected from each species, and the extracellular cellulase and total cellulase activities for four types of cellulase (filter paper enzyme, endoglucanase, exoglucanase, and $\beta$-glucosidase) were determined and compared. These findings represent the first study to analyze the cellulolytic bacterial flora in the rumen of Inner Mongolian sheep. This will be helpful to augment the pool of cellulolytic bacteria and explore new cellulolytic bacteria for biomass utilization.

\section{EXPERIMENTAL}

\section{Materials and Methods Medium}

Medium A: The medium was prepared according to Jian Pang et al. (2017) and adjusted slightly. Five-hundred $\mathrm{mL}$ of basal medium, $165 \mathrm{~mL}$ of inorganic salt solution A, 
$165 \mathrm{~mL}$ of inorganic salt solution $\mathrm{B}, 169 \mathrm{~mL}$ of cell-free rumen fluid, and $1.0 \mathrm{~mL}$ of $0.1 \%$ resazurin were mixed to a total volume of $1000 \mathrm{~mL}$. Basal medium was composed of 5.0 $\mathrm{g} / \mathrm{L} \mathrm{NaHCO} 3,1.0 \mathrm{~g} / \mathrm{L}$ peptone, and $1.0 \mathrm{~g} / \mathrm{L}$ yeast powder. Inorganic salt solution A was composed of $3.0 \mathrm{~g} / \mathrm{L} \mathrm{KH} \mathrm{PO}_{4}, 3.0 \mathrm{~g} / \mathrm{L}(\mathrm{NH} 4)_{2} \mathrm{SO}_{4}, 6.0 \mathrm{~g} / \mathrm{L} \mathrm{NaCl}, 0.4 \mathrm{~g} / \mathrm{L} \mathrm{CaCl} 2 \cdot 2 \mathrm{H}_{2} \mathrm{O}$, and $0.58 \mathrm{~g} / \mathrm{L} \mathrm{MgSO} 4 \cdot 7 \mathrm{H}_{2} \mathrm{O}$. Inorganic salt solution $\mathrm{B}$ was composed of $3.96 \mathrm{~g} / \mathrm{L} \mathrm{K}_{2} \mathrm{HPO}_{4} \cdot 3 \mathrm{H}_{2} \mathrm{O}$. Cell-free rumen fluid was prepared according to the following procedure: the rumen fluid was taken from the rumen of the Inner Mongolian sheep as the candidate and then filtered via a 4-layer cheese cloth. The filtrate was first centrifuged at 5,000 r/min for $15 \mathrm{~min}$ and then at $15000 \mathrm{r} / \mathrm{min}$ for $30 \mathrm{~min}$. The supernatant was added to medium as cell-free rumen fluid.

Medium B (medium for preliminary isolation of strains): $0.05 \mathrm{~g}$ of sodium carboxymethyl cellulose and $0.4 \mathrm{~g}$ of agar were added to $10 \mathrm{~mL}$ of Hungate tube, and then $5 \mathrm{~mL}$ of medium A was added. The rest of the procedure was the same as for medium A.

Medium C (medium for secondary isolation of strains): $1 \mathrm{~g}$ of filter paper was put into a $20 \mathrm{~mL}$ serum bottle, and then $10 \mathrm{~mL}$ of medium A was added. Flanged butyl stoppers and aluminum crimp were used to seal up the serum bottle. All of the media were dispensed under $\mathrm{N}_{2}$ gassing into serum bottles with aluminum crimp and flanged butyl stoppers. After the color of medium turn pale pink from red, $0.5 \mathrm{~mL}$ of $25 \mathrm{~g} / \mathrm{L}$ cysteine hydrochloride was injected to a serum bottle. At last, serum bottles were autoclaved at $121^{\circ} \mathrm{C}$ for $20 \mathrm{~min}$.

Medium D (medium for cellulase enzyme activity determination of selected strains): $0.1 \mathrm{~g}$ cellobiose was placed in a $150 \mathrm{~mL}$ of serum bottle, and then $50 \mathrm{~mL}$ of medium A was added. The remainder of the procedure was the same as for medium A.

The initial $\mathrm{pH}$ value of all of the above media was about 6.8 .

\section{Strains isolation}

Rumen samples were collected from six mature and healthy castrated Inner Mongolian sheep with a mean weight of $30 \mathrm{~kg}$. The sheep were bought from a lab animal supplier in Hohhot (China), approved by the Inner Mongolian Agricultural University ethics committee. They were housed in individual pens and had free access to water at the animal nutrition lab in the Inner Mongolia Agricultural University in Hohhot at an average altitude of $1050 \mathrm{~m}$ with a middle temperature zone and continental monsoon climate (temperature from $-29{ }^{\circ} \mathrm{C}$ to $31{ }^{\circ} \mathrm{C}$ ). Every sheep was fitted with a permanent rumen cannula with a diet of forage to concentrate ratio of 70:30. The forage consisted of $70 \%$ mixed grass containing $11.20 \%$ corn, $6.10 \%$ wheat bran, $10.20 \%$ soybean meal, $1.25 \%$ stone powder, $0.25 \% \mathrm{CaHPO}_{4}, 0.50 \%$ salt, and $0.50 \%$ compound additive. The animals were maintained on their diets for at least 1 month prior to sampling of rumen contents. After feeding at 7:00 am, the rumen contents were sampled at 9:00 am (local time). The collecting tube was $10 \mathrm{~mm}$ in diameter and both solid and liquid contents in the rumen were collected. Rumen samples from each sheep were transferred into a thermos, which was pre-warmed to approximately $39{ }^{\circ} \mathrm{C}$ and filled with carbon dioxide. The rumen samples from all six sheep were mixed, homogenized, serial dilution and then inoculated to medium B by Hungate roll technology for cultivation of strict anaerobes according to the method of Hungate RE (1959) [Hungate, R. E. 1969. A roll-tube method was used for cultivation of strict anaerobes. Methods Microbiol. 3B:117-132.]. Inculum was introduced to melted agar liquid by syringe injection through the rubber closure. Inculated agar tubes were rolled on ice or ice water to solidify the agar in a thin layer and are then incubated for $24 \mathrm{~h}$ to $48 \mathrm{~h}$ in an anaerobic environment $\left(100 \% \mathrm{~N}_{2}\right.$ atmosphere in Hungate tube) at $39{ }^{\circ} \mathrm{C}$. Serial dilutions into additional tubes can be made by syringe as desired. The colonies that 
formed transparent zones on the CMC-Na agar were selected and purified to be single colonies. The isolation process was completed in an anaerobic workstation (Baker Ruskinn Bugbox). For secondary screening, each single colony was inoculated into the medium C with filter paper as the carbon source and energy source, and then incubated at $39^{\circ} \mathrm{C}$ for 7 days. Strains solubilizing filter papers significantly were selected. The isolated cellulolytic strains were preserved at $-80{ }^{\circ} \mathrm{C}$ with $20 \%$ glycerol as protective agent for further research.

\section{Identification of strains}

To save cost and time, the isolated strains were first identified by traditional methods (colony morphology, cell morphology, as well as physiological and biochemical characteristics), and then the selected strains were further identified according to molecular biology methods $((\mathrm{G}+\mathrm{C})$ mol \% content and $16 \mathrm{~S}$ rDNA gene sequencing).

Cell morphologies were observed at their exponential growth phase with phase contrast microscopy (ShangHai Optical Instrument Facotry, ShangHai, China). The physiological and biochemical characteristics were determined via reference to Bergey's manual of systematic bacteriology (Holt et al. 1994). The genomic DNA was extracted using the TaKaRa bacterial DNA extraction kit (TaKaRa, Tokyo, Japan) according to the manufacturer's instructions. The $(\mathrm{G}+\mathrm{C})$ mol \% of the strains was determined with an ultraviolet (UV)-1700 UV-VIS spectrophotometer (Shimadzu Corp., Kyoto, Japan). Escherichia coli $\mathrm{K} 12$ were used as the control strains. The $(\mathrm{G}+\mathrm{C}) \mathrm{mol} \%$ of the test and control strains were determined using the following method: The genomic DNA was dissolved in colorimetric ware in $25 \mathrm{~mol} / \mathrm{L}$ saline sodium citrate buffer (SSC) (saline sodium citrate composed of $0.15 \mathrm{~mol} / \mathrm{L} \mathrm{NaCl}$ and $0.015 \mathrm{~mol} / \mathrm{L}$ sodium citrate) and then slowly heated from $25^{\circ} \mathrm{C}$ (final temp) at a speed of $0.5^{\circ} \mathrm{C} / \mathrm{min}$. The absorbance of the solution at $260 \mathrm{~nm}$ was continuously monitored against a blank that contained only SSC buffer. The $T_{\mathrm{m}}$ value was defined as the temperature at $50 \%$ hyperchromicity. The $(\mathrm{G}+\mathrm{C})$ mol $\%$ of the genomic DNA of the test strain was calculated using Eq. 1:

$$
\left.(\mathrm{G}+\mathrm{C}) \mathrm{mol} \%=51.2+2.08 \times\left(T_{\mathrm{m}} \text { (test strain }\right)-T_{\mathrm{m}}(\text { control strain })\right)
$$

The 16S rDNA gene sequence identification was as follows: The $50 \mu \mathrm{L}$ polymerase chain reaction (PCR) mixtures contained $1.0 \mu \mathrm{L}$ of $100 \mathrm{ng} / \mu \mathrm{L}$ template DNA, $1.0 \mu \mathrm{L}$ of each primer, $25.0 \mu \mathrm{L}$ of $2 \times$ Taq Platinum PCR MasterMix (every $0.5 \mathrm{~mL}$ Platinum PCR MasterMix contained $0.1 \mathrm{U} / \mu \mathrm{L}$ Taq Platinum polymerase, $500 \mu \mathrm{L}$ of deoxy-ribonucleoside triphosphate (dNTP), $50 \mathrm{mmol} / \mathrm{L}$ Tris- $\mathrm{HCl}, 20 \mathrm{mmol} / \mathrm{L} \mathrm{KCl}$, and $4 \mathrm{mmol} / \mathrm{L} \mathrm{MgCl}_{2}$ ), and $22 \mu \mathrm{L}$ of Milli-Q water (Millipore. MA, USA). The primers employed for the amplification were forward primer 27F (5'-AGAGTTTGATCCTGGCTCAG-3') and reverse primer 1492R (5'-ACGGCTACCTTGTTACGACT-3') (Lane 1991). The amplification procedures were as follows: $5 \mathrm{~min}$ at $94{ }^{\circ} \mathrm{C} ; 25$ cycles of $30 \mathrm{~s}$ at $94{ }^{\circ} \mathrm{C}, 30 \mathrm{~s}$ at $55^{\circ} \mathrm{C}$ to 58 ${ }^{\circ} \mathrm{C}$ (different temperatures were used for different strains), and $90 \mathrm{~s}$ at $72{ }^{\circ} \mathrm{C}$; after the cycles, an additional $5 \mathrm{~min}$ at $72{ }^{\circ} \mathrm{C}$. The PCR products were sequenced by Tiangen Biotech Co., Ltd. (Beijing, China), and the results were contrasted with the 16S rDNA gene sequences available in the Genbank from the National Center for Biotechnology Information Database. A similarity of $98 \%$ was considered as the same genera (Clarridge 2004).

\section{Cellulase activities of selected strains}

The strain was inoculated in liquid medium $\mathrm{C}$ with an inoculum size of $2 \%$, and then incubated at $39^{\circ} \mathrm{C}$ under anaerobic conditions for $48 \mathrm{~h}$. Fermentation broth was taken, 
and all samples were diluted to the same absorbance value $\left(\mathrm{OD}_{600}=1\right)$ to ensure the same cell concentration. Each sample was divided into two parts. One part was centrifugated at $4{ }^{\circ} \mathrm{C}$ at $6000 \mathrm{r} / \mathrm{min}$ for $15 \mathrm{~min}$, and supernatant was collected for the determination of extracellular cellulase. The cells in other part were disrupted by ultrasonic waves with a power of $400 \mathrm{~W}$, intermittent frequency of 0.6 , and time of $25 \mathrm{~min}$ to obtain the total cellulase. At last, the extracellular and total cellulase activities were determined and compared. The enzymatic activities of endoglucanase, exoglucanase, glucosidase, and filter paper enzyme were determined according to the method of Ghose (1987). One unit of enzyme activity was defined as the amount of enzyme that released $1.0 \mu \mathrm{g}$ of reducing sugar per minute. Cellulase activities of selected strains were collected from triple replicated experiments. An analysis of variance (ANOVA) for the enzyme activity was conducted using SAS software (Statistical Analysis System, SAS 9.2, Cary, NC, USA).

This study was approved by the Ethical Committee for Animal Experiments of Inner Mongolia Agricultural University (Permit Number: SYXK(Inner Mongolia)20140002). The animal experiment process strictly abides by the British Animals (Scientific Procedures) Act of 1986 and the European Directive 2010/63/EU.

\section{RESULTS AND DISCUSSION}

\section{Strains Isolation}

A total of 96 isolates with transparent zones were obtained from the rumen contents of Inner Mongolian sheep through plating on CMC-Na medium. Based on the calculation of the ratio of the clearance zone diameter to the colony diameter, these bacterial isolates exhibited large differences in their abilities to degrade CMC-Na, and strains with higher ratios of clearance zone diameter to colony diameter were selected for a further filter paper degradation experiment. A total of 22 isolates were obtained by observing the degree of degradation for filter paper. The degradation degree of filter paper is shown in Table 1.

Table 1. Degradation of Filter Paper

\begin{tabular}{|c|c|c|c|c|c|}
\hline Strain & $\begin{array}{c}\text { Degradation } \\
\text { Degree of } \\
\text { Filter Paper }\end{array}$ & Strain & $\begin{array}{c}\text { Degradation } \\
\text { Degree of } \\
\text { Filter Paper }\end{array}$ & Strain & $\begin{array}{c}\text { Degradation } \\
\text { Degree of } \\
\text { Filter Paper }\end{array}$ \\
\hline WH-1 & +++ & CLQ & ++ & NBG & ++++ \\
\hline WH-22 & ++++ & VI3 & +++ & LBG-11 & ++++ \\
\hline WH-3 & ++ & NBQ-1 & +++ & LHG & + \\
\hline WG-1 & +++ & NDF-2 & + & NDF-3 & +++ \\
\hline WHQ & +++ & LBQ-1 & + & LH-1 & ++ \\
\hline LHH-1 & ++ & LHQ-3 & + & LLH & ++ \\
\hline CCQ & +++ & CBQ & + & & \\
\hline LYQ & +++ & X6C1 & + & & \\
\hline \multicolumn{7}{l}{ Note: more +'s represent more breakage }
\end{tabular}

As a result, 22 strains of cellulolytic bacteria were isolated from the rumen of Inner Mongolian sheep using the combined method of transparent zone and filter paper degradation. 


\section{Identification of Strains}

The colony morphologies of the 22 strains are shown in Table 2, and the cell morphologies are shown in Table 3. The physiological and biochemical characteristics of isolates are shown in Table 4.

Table 2. Colony Morphology

\begin{tabular}{|c|c|c|c|c|c|}
\hline $\begin{array}{c}\text { Colony } \\
\text { Parameters }\end{array}$ & $\begin{array}{l}\text { WH-1, WH-22, } \\
\text { WH-3, LHH-1, } \\
\text { WG-1, WHQ }\end{array}$ & CCQ, LYQ & $\begin{array}{c}\text { CLQ, VI3, NBQ- } \\
\text { 1, NDF-2, LBQ-1, } \\
\text { LHQ-3, CBQ, } \\
\text { X6C1 }\end{array}$ & $\begin{array}{l}\text { NBG-1, } \\
\text { LBG-11, } \\
\text { LHG }\end{array}$ & $\begin{array}{c}\text { NDF-3, LH- } \\
1, \text { LLH }\end{array}$ \\
\hline Size(Diameter) & 0.5 to $1 \mathrm{~mm}$ & 1 to $2 \mathrm{~mm}$ & 0.5 to $3 \mathrm{~mm}$ & 2 to $3 \mathrm{~mm}$ & $0.5 \mathrm{~mm}$ \\
\hline Shape & Round & Round & Round & Round & Round \\
\hline Moisture & Wet & Wet & Wet & Wet & Wet \\
\hline Height & Flat & Flat & Flat & Flat & Flat \\
\hline Transparency & Translucent & Translucent & Translucent & Translucent & Translucent \\
\hline Color & White & Yellow & White & Milkiness & Milkiness \\
\hline Edge & Regular & Irregular & Regular & Irregular & Regular \\
\hline Smooth & Smooth & Smooth & Smooth & Smooth & Smooth \\
\hline
\end{tabular}

Table 3. Cell Morphology

\begin{tabular}{|c|c|c|c|c|c|}
\hline $\begin{array}{c}\text { Cell } \\
\text { Parameters }\end{array}$ & $\begin{array}{c}\text { WH-1, WH-22, } \\
\text { WH-3, LHH-1, } \\
\text { WG-1, WHQ }\end{array}$ & CCQ, LYQ, & $\begin{array}{c}\text { CLQ, VI3, NBQ-1, } \\
\text { NDF-2, LBQ-1, } \\
\text { LHQ-3, CBQ, } \\
\text { X6C1 }\end{array}$ & $\begin{array}{c}\text { NBG-1, LBG- } \\
11, \text { LHG }\end{array}$ & $\begin{array}{c}\text { NDF-3, } \\
\text { LH-1, } \\
\text { LLH }\end{array}$ \\
\hline Size $(\mu \mathrm{m})$ & $\begin{array}{c}0.4 \text { to } 0.6 \times 2 \\
\text { to } 5\end{array}$ & $\begin{array}{c}0.3 \text { to } 1.5 \times \\
0.7 \text { to } 1.8\end{array}$ & $\begin{array}{c}0.3 \text { to } 1.5 \times 0.7 \text { to } \\
1.8\end{array}$ & $\begin{array}{c}0.4 \text { to } 0.8 \times \\
0.8 \text { to } 2.0\end{array}$ & $\begin{array}{c}0.6 \text { to } 1 \times \\
3 \text { to } 6\end{array}$ \\
\hline Shape & Vibrio & Cocci & Cocci & Rod & Rod \\
\hline Gram stain & Negative & Positive & Positive & Negative & Negative \\
\hline
\end{tabular}

Table 4(1). Physiological and Biochemical Characteristics of Isolated Strains (1)

\begin{tabular}{|c|c|c|c|c|c|c|c|c|c|c|c|c|c|c|c|}
\hline \multirow{2}{*}{ Strain } & \multirow{2}{*}{ FT } & \multirow{2}{*}{ C } & \multirow{2}{*}{$\mathrm{N}$} & \multirow{2}{*}{$\mathrm{H}_{2} \mathrm{~S}$} & \multirow{2}{*}{ M } & \multicolumn{5}{|c|}{ Temperature Experiments } & \multicolumn{5}{|c|}{ pH Experiments } \\
\hline & & & & & & $20^{\circ} \mathrm{C}$ & $30^{\circ} \mathrm{C}$ & $37^{\circ} \mathrm{C}$ & $39^{\circ} \mathrm{C}$ & $45^{\circ} \mathrm{C}$ & 5.5 & 6.3 & 7.0 & 7.8 & 8.0 \\
\hline $\mathrm{WH}-1$ & Anaerobic & - & - & - & + & ++ & ++ & $\#$ & +++ & + & - & - & $\#$ & - & - \\
\hline WH-22 & Anaerobic & - & - & - & + & ++ & +++ & $\#$ & +++ & + & + & - & \# & + & - \\
\hline WH-3 & Anaerobic & - & - & - & + & + & ++ & \# & +++ & ++ & - & - & \# & - & - \\
\hline LHH-1 & Anaerobic & - & - & - & + & ++ & +++ & $\#$ & +++ & + & - & + & $\#$ & - & - \\
\hline WHQ & Anaerobic & - & - & - & + & + & ++ & \# & +++ & ++ & - & ++ & \# & + & + \\
\hline WG-1 & Anaerobic & - & - & - & + & ++ & ++ & \# & +++ & + & + & ++ & $\#$ & + & + \\
\hline NBG & Anaerobic & - & - & - & + & ++ & ++ & \# & +++ & ++ & + & + & $\#$ & + & - \\
\hline LBG-11 & Anaerobic & - & - & - & + & + & ++ & \# & +++ & ++ & - & - & $\#$ & - & - \\
\hline LHG & Anaerobic & - & - & - & + & ++ & +++ & \# & +++ & ++ & - & - & $\#$ & + & - \\
\hline NDF-3 & Anaerobic & - & - & - & + & ++ & ++ & +++ & $\#$ & ++ & - & - & + & + & - \\
\hline LH-1 & Anaerobic & - & - & - & + & ++ & ++ & +++ & $\#$ & ++ & + & + & $\#$ & + & - \\
\hline LLH & Anaerobic & - & - & - & + & ++ & ++ & ++ & $\#$ & ++ & - & + & $\#$ & + & - \\
\hline $\mathrm{CCQ}$ & Anaerobic & - & - & - & - & - & +++ & +++ & $\#$ & + & + & ++ & $\#$ & + & + \\
\hline LYQ & Anaerobic & - & - & - & - & - & ++ & +++ & $\#$ & + & + & ++ & $\#$ & + & - \\
\hline CLQ & Anaerobic & - & - & - & - & - & ++ & ++ & $\#$ & - & - & + & $\#$ & + & - \\
\hline $\mathrm{VI3}$ & Anaerobic & - & - & - & - & - & +++ & +++ & $\#$ & - & - & - & $\#$ & + & + \\
\hline
\end{tabular}




\begin{tabular}{|c|c|c|c|c|c|c|c|c|c|c|c|c|c|c|c|}
\hline \multirow{2}{*}{ Strain } & \multirow{2}{*}{ FT } & \multirow{2}{*}{$\mathrm{C}$} & \multirow{2}{*}{$\mathrm{N}$} & \multirow{2}{*}{$\mathrm{H}_{2} \mathrm{~S}$} & \multirow{2}{*}{$M$} & \multicolumn{5}{|c|}{ Temperature Experiments } & \multicolumn{5}{|c|}{ pH Experiments } \\
\hline & & & & & & $20^{\circ} \mathrm{C}$ & $30^{\circ} \mathrm{C}$ & $37^{\circ} \mathrm{C}$ & $39^{\circ} \mathrm{C}$ & $45^{\circ} \mathrm{C}$ & 5.5 & 6.3 & 7.0 & 7.8 & 8.0 \\
\hline NBQ-1 & Anaerobic & - & - & - & - & ++ & ++ & +++ & $\#$ & + & + & - & $\#$ & + & - \\
\hline NDF-2 & Anaerobic & - & - & - & - & + & ++ & +++ & \# & + & - & ++ & \# & + & + \\
\hline LBQ-1 & Anaerobic & - & - & - & - & ++ & +++ & +++ & \# & +++ & + & ++ & \# & + & + \\
\hline LHQ-3 & Anaerobic & - & - & - & - & ++ & ++ & \# & $\#$ & +++ & + & ++ & $\#$ & + & - \\
\hline $\mathrm{CBQ}$ & Anaerobic & - & - & - & - & ++ & ++ & ++ & \# & ++ & - & + & $\#$ & + & - \\
\hline X6C1 & Anaerobic & - & - & - & - & ++ & ++ & \# & +++ & ++ & - & ++ & \# & + & - \\
\hline \multirow{2}{*}{ Strain } & \multirow{2}{*}{ FT } & \multirow{2}{*}{ C } & \multirow{2}{*}{$\mathrm{N}$} & \multirow{2}{*}{$\mathrm{H}_{2} \mathrm{~S}$} & \multirow[b]{2}{*}{$M$} & \multicolumn{5}{|c|}{ Temperature Experiments } & \multicolumn{5}{|c|}{$\mathrm{pH}$ Experiments } \\
\hline & & & & & & $20^{\circ} \mathrm{C}$ & $30^{\circ} \mathrm{C}$ & $37^{\circ} \mathrm{C}$ & $39^{\circ} \mathrm{C}$ & $45^{\circ} \mathrm{C}$ & 5.5 & 6.3 & 7.0 & 7.8 & 8.0 \\
\hline Blank & & - & - & - & - & - & - & - & - & - & - & - & - & - & - \\
\hline
\end{tabular}

Table 4(2). Physiological and Biochemical Characteristic of Isolated Strains (2)

\begin{tabular}{|c|c|c|c|c|c|c|c|c|c|c|c|c|c|c|c|}
\hline Strain & G1 & M1 & L & A & R & S1 & S2 & M2 & M3 & F & G2 & E & S3 & G3 & X \\
\hline WH-1 & + & - & - & + & - & - & + & - & - & + & - & - & - & + & + \\
\hline WH-22 & + & - & - & + & - & - & - & - & - & + & - & - & - & + & + \\
\hline WH-3 & + & - & - & + & - & - & - & - & - & + & - & + & - & + & + \\
\hline LHH-1 & + & - & - & + & - & - & - & - & - & + & - & + & + & + & + \\
\hline WHQ-1 & + & - & - & + & - & - & - & - & - & + & - & + & - & + & + \\
\hline WG-1 & + & - & - & + & - & - & - & - & - & + & + & + & - & + & + \\
\hline NBG & + & - & + & - & - & - & + & - & - & - & - & + & - & - & - \\
\hline LBG-11 & + & - & + & - & - & - & - & + & - & - & - & - & - & - & - \\
\hline LHG & + & - & + & + & - & - & - & - & + & - & - & - & + & - & - \\
\hline NDF-3 & - & - & - & + & - & - & + & + & + & - & - & + & - & - & + \\
\hline LH-1 & - & - & - & + & - & - & + & + & + & - & - & + & - & - & + \\
\hline LLH & - & - & - & + & - & - & + & + & + & - & - & + & - & - & + \\
\hline CCQ & - & - & - & - & - & - & + & - & - & - & - & + & - & - & - \\
\hline LYQ & + & - & - & - & - & - & + & - & - & - & - & + & - & - & - \\
\hline CLQ & + & - & - & - & - & - & - & - & - & + & - & + & - & + & + \\
\hline VI3 & + & - & - & - & - & - & - & - & - & + & - & - & - & - & - \\
\hline NBQ-1 & + & - & - & - & + & - & - & - & + & + & - & + & - & + & + \\
\hline NDF-2 & + & + & + & + & + & - & + & + & + & + & - & + & - & + & + \\
\hline LBQ-1 & + & + & + & + & + & + & + & + & + & + & - & + & - & + & + \\
\hline LHQ-3 & + & + & + & + & + & + & - & + & + & + & - & + & - & + & + \\
\hline CBQ & + & + & + & + & + & + & + & + & + & + & - & + & - & + & + \\
\hline X6C1 & + & + & + & + & + & + & + & + & + & + & - & + & - & + & + \\
\hline Blank & - & - & - & - & - & - & - & - & - & - & - & - & - & - & - \\
\hline $\begin{array}{l}\text { Note: }+ \text { Positive; } \\
\text { R: } \text { raffinose; S1: sorbitol; S2: salicin; M2: maltose; M3: melibiose; F: fructose; G2: } \\
\text { glycerol; E: esculin; S3: sodium lactate; G3: galactose; X: D-xylose }\end{array}$ \\
\hline
\end{tabular}

As shown in Tables 2 through 4, the morphological features, the physiological and biochemical characteristics indicated that approximately 22 individual strains were identified. The identification results are shown in Table 5. From the identification results, 
there were six strains of Butyrivibrio fibrisolvens, three strains of Fibrobacter succinogenes, three strains of Clostridium polysaccharolyticum, two strains of Ruminococcus flavefaciens, two strains of Ruminococcus callidus, and one strain of Ruminococcus albus, in the 22 strains of isolates. Five strains of Ruminococcus were only identifiable to the genus level.

Table 5. Traditional Identification Results of 22 Isolates

\begin{tabular}{|c|c|c|c|c|c|c|c|}
\hline Genu & Butyrivibri & \multicolumn{4}{|c|}{ Ruminococcus } & Bacteroide & Clostridium \\
\hline $\begin{array}{c}\text { Speci } \\
\text { es }\end{array}$ & $\begin{array}{c}\text { B.fibrisolve } \\
\text { ns }\end{array}$ & $\begin{array}{c}R . \\
\text { flavefacie } \\
n s\end{array}$ & $\begin{array}{l}\text { R.alb } \\
\text { us }\end{array}$ & $\begin{array}{c}R . \\
\text { callid } \\
\text { us }\end{array}$ & $\begin{array}{l}\text { Unkno } \\
\text { wn }\end{array}$ & $\begin{array}{c}F . \\
\text { succinoge } \\
\text { nes }\end{array}$ & $\begin{array}{l}\text { C.Polysaccharolyti } \\
\text { cum }\end{array}$ \\
\hline Strain & $\begin{array}{l}\text { WH-1, } \\
\text { WH-2, } \\
\text { WH-3, } \\
\text { WG-1, } \\
\text { WHQ, } \\
\text { LHH-1 }\end{array}$ & $\begin{array}{l}\text { CCQ, } \\
\text { LYQ }\end{array}$ & $\mathrm{VI3}$ & $\begin{array}{c}\text { CLQ, } \\
\text { NBQ- } \\
1\end{array}$ & $\begin{array}{l}\text { NDF-2, } \\
\text { LBQ-1, } \\
\text { LHQ-3, } \\
\text { CBQ, } \\
\text { X6C1 }\end{array}$ & $\begin{array}{l}\text { NBG-1, } \\
\text { LBG-1, } \\
\text { LHG }\end{array}$ & NDF-3, LH-1, LLH \\
\hline
\end{tabular}

To ensure that isolates were identified accurately, ten strains that solubilized filter paper well and represented various species were identified using molecular biology methods. The identification results of $(\mathrm{G}+\mathrm{C}) \mathrm{mol} \%$ and $16 \mathrm{~S}$ rDNA were shown in Table 6 . The results showed that molecular biology-based identification was consistent with traditional methods.

Table 6. Molecular Identification of Selected Strains

\begin{tabular}{|c|c|c|c|c|}
\hline Strains & $\begin{array}{c}\mathrm{Tm} \\
\left({ }^{\circ} \mathrm{C}\right)\end{array}$ & $(\mathrm{G}+\mathrm{C}) \mathrm{mol} \%$ & Nearest Valid Taxon & Accession Number \\
\hline WH-1 & 87.45 & 40.7 & Butyrivibrio fibrisolvens & EU106047 \\
\hline WH-22 & 87.02 & 39.8 & Butyrivibrio fibrisolvens & KC438276 \\
\hline WG-1 & 86.06 & 37.8 & Butyrivibrio fibrisolvens & HQ404371 \\
\hline WHQ & 87.21 & 40.2 & Butyrivibrio fibrisolvens & HQ404372 \\
\hline CCQ & 88.65 & 43.2 & Ruminococcus flavefaciens & KC438277 \\
\hline LYQ & 87.11 & 40.0 & Ruminococcus flavefaciens & KC438278 \\
\hline VI3 & 88.75 & 43.4 & Ruminococcus albus & HQ404370 \\
\hline LBG-11 & 90.63 & 47.3 & Fibrobacter succinogenes & KC438280 \\
\hline NBG & 90.58 & 47.2 & Fibrobacter succinogenes & KC438280 \\
\hline NDF-3 & 88.32 & 42.5 & Clostridium polysaccharolyticum & HQ404373 \\
\hline
\end{tabular}

After identification via traditional and molecular biology methods, there were four strains of Butyrivibrio fibrisolvens, two strains of Rumincoccus flavefaciens, two strains of Fibrobacter succinogenes, one strain of Rumincoccus albus, and one strain of Clostridium polysaccharolyticum in the 10 selected microbial strains.

\section{Determination of Cellulase Activities}

One strain was selected from each $R$. albus, $R$. flavefaciens, $F$. succinogenes, and B. fibrisolvens. The extracellular cellulase and total cellulase activities of four types of 
cellulase (endoglucanase, exoglucanase, $\beta$-glucosidase, and filter paper enzyme) are shown in Table 7.

As a result, the total filter paper enzyme activity of the representative strains from $B$. fibrisolvens, $R$. albus, $R$. flavefaciens, and $F$. succinogenes were $19.48 \pm 2.19$ IU, 33.86 $\pm 3.16 \mathrm{IU}, 32.30 \pm 3.99 \mathrm{IU}$, and $47.49 \pm 3.37 \mathrm{IU}$, respectively.

Table 7. Cellulase Activities for Four Strains

\begin{tabular}{|c|c|c|c|c|c|c|c|c|}
\hline Strain & \multicolumn{2}{|c|}{$\begin{array}{c}\text { Filter Paperase } \\
\text { Activity (IU) }\end{array}$} & \multicolumn{2}{|c|}{$\begin{array}{l}\text { Endoglucanase } \\
\text { Activity (IU) }\end{array}$} & \multicolumn{2}{|c|}{$\begin{array}{c}\text { Exoglucanase Activity } \\
\text { (IU) }\end{array}$} & \multicolumn{2}{|c|}{$\begin{array}{c}\beta \text {-Glucosidase Activity } \\
\text { (IU) }\end{array}$} \\
\hline & $\begin{array}{c}\text { Extracellular } \\
\text { Cellulase } \\
\text { Activity }\end{array}$ & $\begin{array}{c}\text { Total } \\
\text { Cellulase } \\
\text { Activity }\end{array}$ & $\begin{array}{c}\text { Extracellular } \\
\text { Cellulase } \\
\text { Activity }\end{array}$ & $\begin{array}{c}\text { Total } \\
\text { Cellulase } \\
\text { Activity }\end{array}$ & $\begin{array}{c}\text { Extracellular } \\
\text { Cellulase } \\
\text { Activity }\end{array}$ & $\begin{array}{c}\text { Total } \\
\text { Cellulase } \\
\text { Activity }\end{array}$ & $\begin{array}{c}\text { Extracellular } \\
\text { Cellulase } \\
\text { Activity }\end{array}$ & $\begin{array}{c}\text { Total } \\
\text { Cellulase } \\
\text { Activity }\end{array}$ \\
\hline VI3 & $\begin{array}{l}4.37 \pm \\
0.33^{a}\end{array}$ & $\begin{array}{c}33.86 \pm \\
3.16^{\mathrm{cA}}\end{array}$ & $\begin{array}{c}10.36 \pm \\
1.16^{\mathrm{a}}\end{array}$ & $\begin{array}{c}66.92 \pm \\
1.57^{c}\end{array}$ & $\begin{array}{l}5.83 \pm \\
0.52^{\mathrm{a}}\end{array}$ & $\begin{array}{c}39.76 \pm \\
1.07 \mathrm{c}\end{array}$ & $\begin{array}{c}33.44 \pm \\
1.69^{a}\end{array}$ & $\begin{array}{c}204.99 \pm \\
8.28^{c}\end{array}$ \\
\hline CCQ & $\begin{array}{l}4.65 \pm \\
0.46^{a}\end{array}$ & $\begin{array}{c}32.30 \pm \\
3.99 \mathrm{cA}\end{array}$ & $\begin{array}{l}9.76 \pm \\
0.58^{a}\end{array}$ & $\begin{array}{l}72.52 \pm \\
3.81^{\mathrm{c}}\end{array}$ & $\begin{array}{l}5.29 \pm \\
0.61^{\mathrm{a}}\end{array}$ & $\begin{array}{l}37.69 \pm \\
2.89 c\end{array}$ & $\begin{array}{c}32.16 \pm \\
1.87^{\mathrm{a}}\end{array}$ & $\begin{array}{c}205.46 \pm \\
4.25^{c}\end{array}$ \\
\hline LBG-1 & $\begin{array}{l}6.33 \pm \\
0.22^{\mathrm{a}}\end{array}$ & $\begin{array}{l}47.49 \pm \\
3.37 \mathrm{cC}\end{array}$ & $\begin{array}{c}10.32 \pm \\
0.62^{a}\end{array}$ & $\begin{array}{l}93.94 \pm \\
5.64^{c}\end{array}$ & $\begin{array}{l}6.85 \pm \\
0.76^{\mathrm{a}}\end{array}$ & $\begin{array}{c}55.33 \pm \\
6.21^{\mathrm{c}}\end{array}$ & $\begin{array}{l}28.32 \pm \\
1.59^{a}\end{array}$ & $\begin{array}{c}222.40 \pm \\
11.94^{c}\end{array}$ \\
\hline $\mathrm{WH}-1$ & $\begin{array}{l}2.77 \pm \\
0.13^{\mathrm{a}}\end{array}$ & $\begin{array}{l}19.48 \pm \\
2.19^{\mathrm{cE}}\end{array}$ & $\begin{array}{l}4.13 \pm \\
0.19^{a}\end{array}$ & $\begin{array}{c}38.66 \pm \\
3.78^{c}\end{array}$ & $\begin{array}{l}3.29 \pm \\
0.20^{\mathrm{a}}\end{array}$ & $\begin{array}{c}24.69 \pm \\
2.04^{c}\end{array}$ & $\begin{array}{l}17.91 \pm \\
0.49^{a}\end{array}$ & $\begin{array}{c}106.33 \pm \\
11.74^{c}\end{array}$ \\
\hline
\end{tabular}

\section{Discussion on the Difference in Enzyme Activity}

Most isolates with transparent circles on the CMC-Na plate did not effectively degrade the filter paper. The results showed that multiple bacterial isolates from the rumen of Inner Mongolian sheep degraded CMC-Na and did not degrade the filter paper because CMC-Na was degraded by endoglucanase, whereas the filter paper was degraded by the mixture or complex of endoglucanase, exoglucanase, and $\beta$-glucanase. Many carboxymethyl cellulose (CMCases) have minimal capacity to digest native insoluble cellulose, and many non-cellulolytic ruminal bacteria can hydrolyze CMC-Na even though they cannot utilize native cellulose as a substrate for growth (Avguštin et al. 1997; Fields et al. 1998). The CMCase activity was not strongly correlated with cellulose utilization (Fields et al. 1998) because all CMCase-positive, cellobiose-utilizing ruminal bacteria grew on $\beta$-glucan, and CMCases appear to be a mechanism for the utilization of watersoluble mixed $\beta$-glucans rather than native cellulose (Fields et al. 1998). The combined method of transparent zone and filter paper degradation was used in this study because the transparent zone method can save time and the filter paper degradation experiment can accurately select cellulose-solubilizing bacteria. Kong et al. (2012) studied the rumen of cattle fed alfalfa or triticale by fluorescence in situ hybridization (FISH), and the results indicated that CMC-Na-digesting bacteria contributed between $8.2 \%$ and $10.1 \%$ to the total bacterial cell numbers. In the study, some CMC-Na solubilizing bacteria were isolated from the rumen of Inner Mongolian sheep, which also indicated that rumen of Inner Mongolian sheep contained a huge pool for cellulolytic microorganisms because they, 
through evolution, have a high tolerance for heterogeneous and plant polysaccharide-rich foraged materials.

The number of $B$. fibrisolvens was highest among the isolated 10 strains. Although $B$. fibrisolvens were not considered as the main cellulolytic strain in early studies (Michalet-Doreau et al. 2001), recent studies have verified the importance of $B$. fibrisolvens both in number and cellulolytic activity in rumen via molecular biology and traditional culture methods (Hess et al. 2011; Kenters et al. 2011; Nyonyo et al. 2013). Hess et al. (2011) demonstrated that the gene of B. fibrisolvens comprised of a substantial proportion in the metagenome of rumen and played an important role in the deconstruction of fiber via metagenomic analysis. In recent rumen microbiome studies (Edwards et al. 2017), B. fibrisolvens also were found as a major species. Kenters et al. (2011) isolated four strains of $R$. albus, six strains of $R$. flavefaciens, eleven strains of $B$. fibrisolvens, and two strains of $C$. polysaccharolyticum from the rumen of cows in New Zealand with pasture hay after $48 \mathrm{~h}$ of exposure to a rye-grass clover pasture. Nyonyo et al. (2013) isolated three strains of Ruminococcus, one strain of Fibrobacter, two strains of Clostridium, and twentyone strains of Butyrivibrio from the rumen of Holstein cows using a novel anaerobic media. Nyonyo et al. (2014) isolated 129 strains from the rumen of Holstein cows, and there were twenty-two strains of Butyrivibrio, one strain of Enterococcus, five strains of Ruminococcus, one strain of Clostridium cluster IV, and three strains of Fibrobacter. Molecular biology has allowed more detailed and accurate analyses of rumen microbial flora.

Intra-genomic heterogeneity of $16 \mathrm{~S}$ rDNA genes can also cause overestimation of microbiological strains (Sun et al. 2013). Thus, cultivation in vitro is still a good approach to the analysis of rumen microbial flora. As shown in Table 7, the filter paperase activity was lower than that of endoglucanase, exdoglucanase, and $\beta$-glucosidase activities in the same strain because the filter paperase activity is the sum of other three types of enzyme activities. Exoglucanase activity was close to the filter paperase enzyme activity and lower than the endoglucanase and $\beta$-glucosidase activities because exoglucanase activity was identified as the rate-limiting enzyme in cellulose degradation (Lynd et al. 2002). The total cellulase activity significantly increased compared with the extracellular cellulase activity $(\mathrm{P}<0.01)$ because substantial cellulase comprises intracellular enzyme, extracellular enzyme, and enzymes that connect to cells (Weimer et al. 1990; Gong and Forsberg 1993). The filter paperase activity of LBG-1, VI3, CCQ, and WH-1 exhibited a decreasing trend. The filter paperase activity of LBG-1 was higher than VI3 and CCQ (P<0.01), and no significant difference was identified between VI3 and CCQ $(\mathrm{P}>0.05)$. The filter paperase activity of CCQ was higher than WH-1 (P<0.01). There were different conclusions regarding the cellulase activity of $R$. albus, $R$. flavefaciens, and $F$. succinogenes. Miron (1993) reported that $F$. succinogenes $\mathrm{S} 85$ digested more cellulose from cellulolytic material in vitro than the two other predominant cellulolytic bacterial species, $R$. albus and $R$. flavefaciens. Nyonyo et al. (2014) isolated 129 strains from the rumen of Holstein cows. The results indicated that 51, 117, and 105 strains had filter paperase, carboxymethylcellulase, and xylanase activities, respectively, and 44 strains had both filter paperase and CMCase activities. The filter paperase activity was in an order of $R$. albus, $R$. flavefaciens, F. succinogenes, Clostridium cluster IV, and B. fibrisolvens. The difference in enzyme activity was caused by the difference in different strains. 


\section{CONCLUSIONS}

1. Cellulolytic bacterial flora in the rumen of Inner Mongolian sheep included $B$. fibrisolvens, $R$. flavefaciens, $F$. succinogenes, $R$. albus, $R$. callidus, $C$. polysaccharolyticum. The B. fibrisolvens species made up the largest proportion of the microbiome.

2. The total cellulase activity of the representative strains from B. fibrisolvens, R. albus, $R$. flavefaciens, and $F$. succinogenes were high.

3. The rumen microbiome of Inner Mongolian sheep represents an important source for cellulolytic microorganisms and enzymes.

\section{ACKNOWLEDGMENTS}

This work was supported by the National Natural Science Foundation of China (NSFC) (Grant No. 61361016); Natural Science Foundation of Inner Mongolia, China (2018MS02019); Foundation of Talent Development of Inner Mongolia, the "Prairie talent" project of Inner Mongolia; and the Inner Mongolia Autonomous Region Science and Technology major projects, Inner Mongolia Science and Technology Plan Project, Inner Mongolia Science and Technology Achievement Conversion Project. The authors are thankful for the help of Jiangxin Wang in proofreading this manuscript.

\section{REFERENCES CITED}

Avguštin, G., Wallace, R. J., and Flint, H. J. (1997). "Phenotypic diversity among ruminal isolates of Prevotella ruminicola: Proposal of Prevotella brevis sp. Nov., Prevotella bryantii sp. Nov., and Prevotella albensis sp. Nov. and redefinition of Prevotella ruminicola," Int. J. Syst. Evol. Micr. 47(2), 284-288. DOI: 10.1099/00207713-47-2284

Clarridge, J. E. (2004). "Impact of 16S rRNA gene sequence analysis for identification of bacteria on clinical microbiology and infectious diseases," Clin. Microbiol. Rev. 17(4), 840-862. DOI: 10.1128/CMR.17.4.840-862.2004

Edwards, H. D., Shelver, W. L., Choi, S., Nisbet, D. J., Krueger, N. A., Anderson, R. C., and Smith, S. B. (2017). "Immunogenic inhibition of prominent ruminal bacteria as a means to reduce lipolysis and biohydrogenation activity in vitro," Food Chemistry 218, 372-377. DOI: 10.1016/j.foodchem.2016.09.052

Fields, M. W., Russell, J. B., and Wilson, D. B. (1998). "The role of ruminal carboxymethylcellulases in the degradation of $\beta$-glucans from cereal grain," FEMS Microbiol. Ecol. 27(3), 261-268. DOI: 10.1111/j.1574-6941.1998.tb00542.x

Ghasemi, S., Naserian, A. A., Valizadeh, R., Tahmasebi, A. M., Vakili, A. R., Behgar, M., and Ghovvati, S. (2012). "Inclusion of pistachio hulls as a replacement for alfalfa hay in the diet of sheep causes a shift in the rumen cellulolytic bacterial population," Small Ruminant Res. 104(1-3), 94-98. DOI: 10.1016/j.smallrumres.2011.09.052

Ghose, T. K. (1987). "Measurement of cellulase activities," Pure Appl. Chem. 59(2), 257268. DOI: 10.1016/j.smallrumres.2011.09.052

Gong, J., and Forsberg, C. W. (1993). "Separation of outer and cytoplasmic membranes 
of Fibrobacter succinogenes and membrane and glycogen granule locations of glycanases and cellobiase," J. Bacteriol. 175(21), 6810-6821. DOI:

10.1128/jb.175.21.6810-6821.1993

Grilli, D. J., Cerón, M. E., Paez, S., Egea, V., Schnittger, L., Cravero, S., Escudero, M. S., Allegretti, L., and Arenas, G. N. (2013). "Isolation of Pseudobutyrivibrio ruminis and Pseudobutyrivibrio xylanivorans from rumen of Creole goats fed native forage diet," Folia Microbiol. 58(5), 367-373. DOI: 10.1007/s12223-012-0219-1

Hamelinck, C. N., Hooijdonk, G. V., and Faaij, A. P. (2005). "Ethanol from lignocellulosic biomass: Techno-economic performance in short-, middle- and longterm," Biomass Bioenerg. 28(4), 384-410. DOI: 10.1016/j.biombioe.2004.09.002

Hess, M., Sczyrba, A., Egan, R., Kim, T., Chokhawala, H., Schroth, G., Luo, S., Clark, D. S., Chen, F., and Zhang, T. (2011). "Metagenomic discovery of biomass-degrading genes and genomes from cow rumen," Science 331(6016), 463-467. DOI: 10.1126/science. 1200387

Holt, J. G., Krieg, N. R., Sneath, P. H., Staley, J. T., and Williams, S. T. (1994). Bergey's Manual of Determinative Bacteriology, $9^{\text {th }}$ Ed., Williams \& Wilkins, Baltimore, MD.

Hungate, R. E. (2013). The Rumen and Its Microbes, Elsevier, Amsterdam, Netherlands.

Kenters, N., Henderson, G., Jeyanathan, J., Kittelmann, S., and Janssen, P. H. (2011). "Isolation of previously uncultured rumen bacteria by dilution to extinction using a new liquid culture medium," J. Microbiol. Meth. 84(1), 52-60. DOI:

10.1016/j.mimet.2010.10.011

Lane, D. J. (1991). "16S/23S rRNA sequencing," in: Nucleic Acid Techniques in Bacterial Systematics, E. Stackebrandt, and M. Goodfellow (eds.), John Wiley \& Sons, Chichester, UK, pp. 115-175.

Lim, D. K. Y., Schuhmann, H., Sharma, K., and Schenk, P. M. (2015). "Isolation of highlipid Tetraselmis suecica strains following repeated UV-C mutagenesis, FACS, and high-throughput growth selection," Bioenerg. Res. 8(2), 750-759. DOI: 10.1007/s12155-014-9553-2

Lynd, L. R., Laser, M. S., Bransby, D., Dale, B. E., Davison, B., Hamilton, R., Himmel, M., Keller, M., McMillan, J. D., and Sheehan, J. (2008). "How biotech can transform biofuels," Nat. Biotechnol. 26(2), 169-172. DOI: 10.1038/nbt0208-169

Lynd, L. R., Weimer, P. J., Van Zyl, W. H., and Pretorius, I. S. (2002). "Microbial cellulose utilization: Fundamentals and biotechnology," Microbiol. Mol. Biol. R. 66(3), 506-577. DOI: 10.1128/MMBR.66.3.506-577.2002

Michalet-Doreau, B., Fernandez, I., Peyron, C., Millet, L., and Fonty, G. (2001). "Fibrolytic activities and cellulolytic bacterial community structure in the solid and liquid phases of rumen contents," Reproduction Nutrition Development 41(2), 187194. DOI: $10.1051 /$ rnd:2001122

Nouaille, R., Matulova, M., Pätoprstý, V., Delort, A. M., and Forano, E. (2009). "Production of oligosaccharides and cellobionic acid by Fibrobacter succinogenes S85 growing on sugars, cellulose and wheat straw," Appl. Microbiol. Biot. 83(3), 42533. DOI: $10.1007 / \mathrm{s} 00253-009-1884-0$

Nyonyo, T., Shinkai, T., and Mitsumori, M. (2014). "Improved culturability of cellulolytic rumen bacteria and phylogenetic diversity of culturable cellulolytic and xylanolytic bacteria newly isolated from the bovine rumen," FEMS Microbiol. Ecol. 88(3), 528-537. DOI: 10.1111/1574-6941.12318

Nyonyo, T., Shinkai, T., Tajima, A., and Mitsumori, M. (2013). "Effect of media composition, including gelling agents, on isolation of previously uncultured rumen 
bacteria," Lett. Appl. Microbiol. 56(1), 63-70. DOI: 10.1111/lam.12019

Patel, D. D., Patel, A. K., Parmar, N. R., Shah, T. M., Patel, J. B., Pandya, P. R., and Joshi, C. G. (2014). "Microbial and carbohydrate active enzyme profile of buffalo rumen metagenome and their alteration in response to variation in the diet," Gene 545(1), 88-94. DOI: 10.1016/j.gene.2014.05.003

Pitta, D. W., Indugu, N., Kumar, S., Vecchiarelli, B., Sinha, R., Baker, L. D., and Ferguson, J. D. (2016). "Metagenomic assessment of the functional potential of the rumen microbiome in Holstein dairy cows," Anaerobe 38, 50-60. DOI:

10.1016/j.anaerobe.2015.12.003

Pitta, D. W., Kumar, S., Veiccharelli, B., Parmar, N., Reddy, B., and Joshi, C. G. (2014). "Bacterial diversity associated with feeding dry forage at different dietary concentrations in the rumen contents of Mehshana buffalo (Bubalus bubalis) using 16S pyrotags," Anaerobe 25(1), 31-41. DOI: 10.1016/j.anaerobe.2013.11.008

Pang, J., Liu, Z. Y., Hao, M., Zhang, Y. F., \& Qi, Q. S. (2017). “An isolated cellulolytic Escherichia coli from bovine rumen produces ethanol and hydrogen from corn straw," Biotechnology for biofuels 10(1), 165. DOI: 10.1186/s13068-017-0852-7

Sanchez, O., and Cardona, C. (2008). "Trends in biotechnological production of fuel ethanol from different feedstocks," Bioresource Technol. 99(13), 5270-5295. DOI: 10.1016/j.biortech.2007.11.013

Sanderson, K. (2006). "US biofuels: A field in ferment," Nature 444, 673-676. DOI: $10.1038 / 444673 a$

Sun, D., Jiang, X., Wu, Q. L., and Zhou, N. (2013). "Intragenomic heterogeneity of 16S rRNA genes causes overestimation of prokaryotic diversity," Appl. Environ. Microbiol. 79(19), 5962-5969. DOI: 10.1128/AEM.01282-13

Thomas, F., Hehemann, J., Rebuffet, E., Czjzek, M., and Michel, G. (2011). "Environmental and gut bacteroidetes: The food connection," Front. Microbiol 2, Article No. 93. DOI: 10.3389/fmicb.2011.00093

Weimer, P. J., Lopez-Guisa, J. M., and French, A. D. (1990). "Effect of cellulose fine structure on kinetics of its digestion by mixed ruminal microorganisms in vitro," Appl. Environ. Microbiol. 56(8), 2421-2429. DOI: 10.1002/bit.260360414

Weimer, P. J., Nerdahl, M., and Brandl, D. J. (2015). "Production of medium-chain volatile fatty acids by mixed ruminal microorganisms is enhanced by ethanol in coculture with Clostridium kluyveri," Bioresource Technol. 175, 97-101. DOI: 10.1016/j.biortech.2014.10.054

Article submitted: May 25, 2019; Peer review completed: August 13, 2019; Revised version received: September 28, 2019; Accepted: September 29, 2019; Published: October 16, 2019. DOI: $10.15376 /$ biores.14.4.9544-9556 